\title{
Pengaruh literasi ekonomi, minat belajar, dan gaya hidup terhadap manajemen uang saku siswa kelas XI IPS SMA Negeri 1 Karangrejo
}

\author{
Nurul Mahmudah, Sri Umi Mintarti Widjaja* \\ Universitas Negeri Malang, Jl. Semarang No. 5 Malang, Jawa Timur, Indonesia \\ *Penulis korespondensi, Surel: sri.umi.fe@um.ac.id
}

Paper received: 6-8-2021; revised: 20-8-2021; accepted: 28-8-2021

\begin{abstract}
This study aims to determine the effects of economic literacy, interest in learning, and lifestyle on pocket money management of students IPS $11^{\text {th }}$ grade in SMA Negeri 1 Karangrejo. The type of study is a descriptive quantitative. The amount of population in this study is 171 students. The sample used is 120 students by using proportional random sampling. Data collection methods are tests and questionnaires distributed online. The results showed that students had a level of economic literacy in the sufficient category, high interest in learning, lifestyle in the high category, and pocket money management which is classified as high. The results also indicate that the variable of economic literacy has no significant effect on the management of student's pocket money, while the variables of learning interest and lifestyle have a significant effect on the management of student's pocket money. In this study, it was found that students need to improve economic literacy to find out the basis for making good economic decisions in everyday life.
\end{abstract}

Keywords: economic literacy; learning interest; lifestyle; pocket money management

\begin{abstract}
Abstrak
Penelitian ini bertujuan untuk mengetahui pengaruh literasi ekonomi, minat belajar, dan gaya hidup terhadap manajemen uang saku siswa kelas XI IPS SMA Negeri 1 Karangrejo. Jenis penelitian ini adalah deskriptif kuantitatif. Jumlah populasi dalam penelitian ini adalah 171 siswa. Sampel yang digunakan berjumlah 120 siswa dengan menggunakan proportional random sampling. Metode pengumpulan data adalah tes dan kuesioner yang disebar secara online. Hasil penelitian menunjukkan bahwa siswa memiliki tingkat literasi ekonomi dalam kategori cukup, minat belajar yang tergolong tinggi, gaya hidup dalam kategori tinggi, dan manajemen uang saku yang tergolong tinggi. Hasil penelitian juga mengindikasikan bahwa variabel literasi ekonomi tidak berpengaruh secara signifikan terhadap manajemen uang saku siswa, sedangkan variabel minat belajar dan gaya hidup berpengaruh secara signifikan terhadap manajemen uang saku siswa. Dalam penelitian ini ditemukan bahwa siswa perlu meningkatkan literasi ekonomi untuk mengetahui dasar pengambilan keputusan ekonomi yang baik dalam kehidupan sehari-hari.
\end{abstract}

Kata kunci: literasi ekonomi; minat belajar; gaya hidup; manajemen uang saku

\section{Pendahuluan}

Era globalisasi menyebabkan banyak produk yang menawarkan kemudahan dan kemewahan dalam memenuhi kebutuhan manusia. Perdagangan menjangkau pasar yang lebih luas. Produk-produk tersebut pun mendorong seseorang tidak bijak dalam mengelola uang mereka. Iklan-iklan yang dikemas dengan menarik di berbagai platform media sosial juga menjadi faktor peningkatan konsumerisme di berbagai kalangan. Strategi pemasaran yang dirancang dengan baik ditambah dengan fasilitas yang diberikan oleh kemajuan teknologi, seperti semakin mudahnya sistem pembayaran mengakibatkan transaksi jual beli terjadi dengan frekuensi lebih cepat. Menurut Priyadana (2019) konsumen di Indonesia didominasi 
oleh masyarakat yang usianya muda dan melek internet. Akibatnya banyak produsen yang memanfaatkan kesempatan ini untuk menargetkan remaja sebagai konsumen utama dan meningkatkan keuntungan sebanyak-banyaknya.

Pada dasarnya, siswa diberi uang saku dari kedua orang tua untuk dibelanjakan dalam rangka menunjang kegiatan belajar mereka. Menurut Fiqriyah dkk (2016:3), uang saku merupakan uang yang diberikan orang tua kepada anak yang dimaksudkan untuk memenuhi kebutuhan selama berada di sekolah. Namun seringnya, uang tersebut tidak dialokasikan dengan baik atau dihabiskan untuk kebutuhan non-sekolah. Misalnya bermain game, belanja produk di online shop, nongkrong di kafe, dan sebagainya.

Sulitnya remaja dalam membedakan antara kebutuhan dan keinginan menjadi permasalahan karena pengelolaan uang mulai didasarkan pada sikap tidak rasional. Menurut Gahagho, dkk (2021:544) pengelolaan keuangan adalah suatu kegiatan pengelolaan dana dalam kehidupan sehari-hari yang dilakukan oleh individu atau kelompok yang ingin mendapatkan kesejahteraan. Beberapa dari remaja atau siswa kurang maksimal dalam menggunakan uang saku dan sebagian lain mampu mengelola tapi tidak mampu bertanggungjawab (leksono, 2018). Ketidakmampuan dalam manajemen uang saku ini dapat merugikan mereka sendiri.

Terdapat beberapa faktor yang menyebabkan seorang siswa mampu melakukan manajemen uang saku. Salah satunya adalah literasi ekonomi yang mereka miliki. Hal ini sejalan dengan penelitian yang dilakukan oleh Ulfah (2013) bahwa literasi ekonomi berpengaruh terhadap tindakan ekonomi. Hariani (Rosidah, 2019) mengungkapkan literasi ekonomi merupakan kemampuan untuk mengerti makna dan arti tentang ilmu ekonomi. Menurut Ulfah (2013:4), manusia yang memiliki pengetahuan cenderung mempunyai kecakapan hidup yang lebih baik. Jadi, literasi ekonomi menjadi salah satu faktor yang sangat penting dalam pengambilan keputusan ekonomi.

Faktor kedua yang mempengaruhi manajemen uang saku siswa adalah minat belajar. Menurut penelitian yang dilakukan oleh Chasanah (2018) bahwa minat belajar berpengaruh positif dan signifikan terhadap manajemen uang saku. Hamalik (Chasanah, 2018) mengungkapkan minat ikut mendorong motivasi perbuatan belajar siswa. Orang tua berperan penting memotivasi anak untuk belajar bagaimana mengelola keuangan. Selain itu, para pengajar di sekolah juga berperan memberi pengarahan agar seorang siswa memiliki rasa ingin tahu yang besar terhadap hal-hal baru. Ini dimaksudkan untuk mendorong siswa mencari pengalaman terhadap hal baru tersebut dalam bentuk perilaku. Siswa yang memiliki minat belajar tinggi di bidang ekonomi cenderung memiliki pengelolaan uang saku yang lebih baik sesuai prinsip-prinsip ekonomi.

Faktor selanjutnya yang mempengaruhi manajemen uang saku adalah gaya hidup. Menurut Azizah (2020:99), gaya hidup yang dijalankan individu memiliki dampak yang kuat dan dapat mempengaruhi perilaku keuangan. Hal ini sejalan dengan penelitian yang dilakukan oleh Fitriani (2018) bahwa gaya hidup berpengaruh positif terhadap perilaku konsumsi. Remaja adalah generasi yang mudah terpengaruh oleh berkembangnya zaman. Globalisasi mendorong akses teknologi yang lebih mudah, sehingga tiap individu diperkenalkan oleh gaya hidup yang beraneka ragam dari berbagai belahan dunia. Beberapa kebutuhan tertentu dapat menyebabkan peningkatan kepercayaan diri dan menunjang penampilan agar diterima oleh 
lingkungan. Namun, seringkali kebutuhan-kebutuhan tersebut dikonsumsi untuk memenuhi gaya hidup yang tidak sehat.

Dari pengamatan inilah, alasan peneliti melakukan penelitian pada siswa kelas XI IPS adalah karena pada umur tersebut, mereka dianggap memiliki literasi ekonomi yang lebih baik. Hal ini dikarenakan sistem pendidikan yang diterapkan merupakan kurikulum 2013 di mana sejak kelas X telah dilakukan penjurusan, sehingga siswa mendapatkan pelajaran ekonomi yang lebih intensif. Alasan kedua adalah siswa kelas XI IPS dianggap memiliki minat belajar yang cukup kuat. Ini dikarenakan minat belajar dapat tumbuh dari bertambahnya pengetahuan terkait sesuatu atau kegiatan yang secara intensif sering dilakukan.

Pemilihan lokasi penelitian disebabkan oleh SMA Negeri 1 Karangrejo cukup jauh dari pusat kota di mana perilaku konsumtif dan irasional dapat ditekan. Selain itu, sekolah ini menerapkan sistem zonasi dalam pendaftaran siswa baru di mana sekitar 50\% siswa bertempat tinggal di daerah tersebut. Dari dua alasan ini, siswa dianggap memiliki karakteristik gaya hidup yang sederhana dan rasional.

\section{Metode}

Penelitian ini menggunakan pendekatan deskriptif kuantitatif untuk mengetahui pengaruh variabel literasi ekonomi (X1) terhadap variabel manajemen uang saku (Y), variabel minat belajar (X2) terhadap variabel manajemen uang saku (Y), dan variabel gaya hidup (X3) terhadap variabel manajemen uang saku (Y). Adapun rancangan penelitian sebagai berikut:

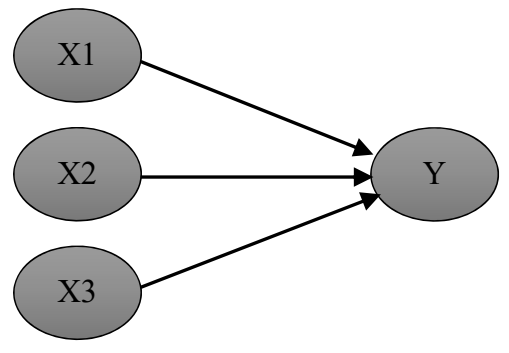

\section{Sumber: Data Olahan Penulis}

Gambar 1. Rancangan Penelitian

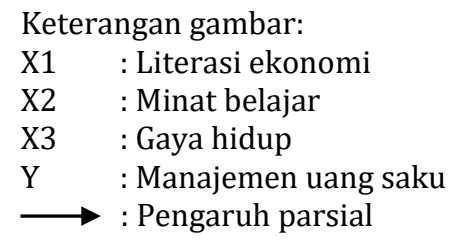

Populasi dalam penelitian ini adalah keseluruhan siswa kelas XI IPS SMA Negeri 1 Karangrejo di Kabupaten Tulungagung yang berjumlah 171 siswa dan terdiri dari 5 kelas. Untuk mengetahui penentuan banyaknya sampel pada populasi tertentu, maka penetapan jumlah sampel pada penelitian ini menggunakan Rumus Slovin dan menghasilkan 120 sampel. Pendistribusian sampel menggunakan teknik proportional random sampling. Teknik pengumpulan data dilakukan dengan tes dan kuesioner. Teknik analisis data meliputi uji hipotesis, analisis regresi linier berganda, koefisien determinasi, dan sumbangan efektif dengan bantuan SPSS 22.00. 


\section{Hasil dan Pembahasan}

Hasil penelitian menunjukkan siswa kelas XI IPS SMA Negeri 1 Karangrejo memiliki tingkat literasi ekonomi dalam kategori sangat tinggi sebesar $13.33 \%$, kategori tinggi sejumlah $31.67 \%$, sebagian besar dalam kategori cukup sebesar 36.67\%, kategori rendah sejumlah $16.67 \%$, dan kategori sangat rendah sebesar $1.67 \%$ dari jumlah sampel. Tingkat minat belajar siswa kelas XI IPS SMA Negeri 1 Karangrejo dapat dideskripsikan dengan kategori sangat tinggi sebesar 15.83\%, sebagian besar dalam kategori tinggi sejumlah 78.33\%, dan kategori cukup sebesar 5.83\% dari jumlah sampel. Kondisi gaya hidup siswa kelas XI IPS SMA Negeri 1 Karangrejo ditunjukkan dalam kategori cukup sebesar 6.67\%, sebagian besar dalam kategori rendah sejumlah $66.67 \%$, dan kategori sangat rendah sebesar $26.67 \%$ dari jumlah sampel. Sedangkan gambaran manajemen uang saku siswa kelas XI IPS SMA Negeri 1 Karangrejo dideskripsikan dengan kategori sangat tinggi sebesar $37.5 \%$, sebagian besar dalam kategori tinggi sejumlah 59.17\%, dan kategori cukup sebesar 3.33\% dari jumlah sampel.

Berdasarkan analisis data penelitian yang dilakukan, maka dapat dijabarkan uji hipotesis sebagai berikut.

Tabel 1. Hasil Uji F

\begin{tabular}{lllllll}
\multicolumn{7}{c}{ ANOVA $^{\mathbf{a}}$} \\
\hline Model & & Sum of Squares & Df & Mean Square & F & Sig. \\
\hline 1 & Regression & 866.391 & 3 & 288.797 & 25.549 & $.000^{\mathrm{b}}$ \\
& Residual & 1311.201 & 116 & 11.303 & & \\
& Total & 2177.592 & 119 & & & \\
\hline
\end{tabular}

a. Dependent Variable: Manajemen Uang Saku

b. Predictors: (Constant), Gaya Hidup, Literasi Ekonomi, Minat Belajar

Sumber: Pengolahan Data SPSS 22, 2021

Berdasarkan tabel 1, nilai signifikansi F sebesar $0.000<0.05$, maka model analisis regresi adalah signifikan. Hal ini berarti Ho ditolak dan Ha diterima. Dengan demikian, variabel bebas yaitu literasi ekonomi (X1), minat belajar (X2), gaya hidup (X3), secara bersama-sama mempengaruhi variabel terikat manajemen uang saku siswa kelas XI IPS SMAN 1 Karangrejo (Y)

Tabel 2. Hasil Uji t

\begin{tabular}{lllll}
\hline & & \multicolumn{3}{l}{ Unstandardized Coefficients } \\
Model & $\mathrm{B}$ & Std. Error & Sig. \\
\hline $1 \quad$ (Constant) & 18.555 & 4.477 & .000 \\
& Literasi & .010 & .080 & .898 \\
& Ekonomi & & .112 & .000 \\
& Minat Belajar & .824 & .134 & .008 \\
\multicolumn{1}{r}{ Gaya Hidup } & -.362 &
\end{tabular}

Sumber: Pengolahan Data SPSS 22, 2021

Berdasarkan tabel 2 menunjukkan bahwa nilai signifikansi X1 > 0.05, X2 < 0.05, dan X3 $<0.05$, sehingga dapat ditarik kesimpulan bahwa tidak terdapat pengaruh signifikan antara literasi ekonomi terhadap manajemen uang saku siswa kelas XI IPS SMAN 1 Karangrejo, sementara minat belajar dan gaya hidup berpengaruh secara signifikan terhadap manajemen uang saku siswa kelas XI IPS SMAN 1 Karangrejo.

Adapun hasil analisis regresi linier berganda, yakni sebagai berikut: 
Tabel 3. Hasil Analisis Regresi Linier Berganda

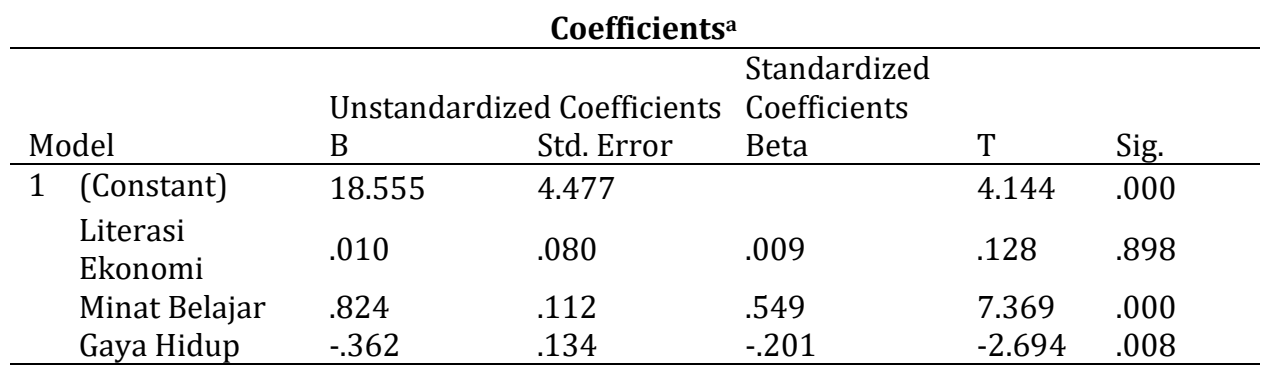

a. Dependent Variable: Manajemen Uang Saku

Sumber: Pengolahan Data SPSS 22, 2021

Berdasarkan tabel 3, dapat diketahui nilai konstanta yaitu 5.961, koefisien regresi literasi ekonomi (X1) yaitu 0.010, koefisien regresi minat belajar (X2) yaitu 0.824, dan koefisien gaya hidup (X3) sebesar -0.362. Dari hasil regresi inilah dapat disusun persamaan rumus:

$$
\begin{gathered}
\mathrm{y}=a+\beta_{1} x_{1}+\beta_{2} x_{2}+\beta_{3} x_{3}+e \\
=18.555+0.010 x_{1}+0.824 x_{2}-0.362 x_{3}+e
\end{gathered}
$$

Persamaan di atas dapat dijelaskan sebagai berikut:

Constanta $(\mathrm{a}=18.555)$

Nilai konstanta ini menunjukkan bahwa jika variabel bebas literasi ekonomi (X2), minat belajar (X2), gaya hidup (X3) dianggap konstan maka hasil variabel terikat manajemen uang saku (Y) sebesar 18.555

Variabel X1 $\left(\beta_{1}=0.010\right)$

Nilai koefisien regresi X1 ( $\left.\beta_{1}\right)$ menunjukkan ketika variabel literasi ekonomi (X1) mengalami kenaikan 1 satuan, maka dapat menambah variabel perilaku manajemen uang saku (Y) sebesar 0.010 dengan asumsi variabel lain dianggap konstan.

Variabel X2 $\left(\beta_{2}=0.824\right)$

Nilai koefisien regresi X2 ( $\left.\beta_{2}\right)$ menunjukkan ketika variabel minat belajar (X2) mengalami kenaikan 1 satuan, maka dapat menambah variabel manajemen uang saku (Y) sebesar 0.824

Variabel X3 $(\beta 3=-0.362)$

Nilai koefisien regresi X3 ( $\beta 3$ ) menunjukkan ketika variabel gaya hidup (X3) mengalami kenaikan 1 satuan, maka dapat menurunkan variabel manajemen uang saku (Y) sebesar -0.362

e. $e$ merupakan standar kesalahan dalam penelitian

Adapun hasil koefisien determinasi dapat dilihat pada tabel berikut:

Tabel 4. Koefisien Determinasi 


\begin{tabular}{|c|c|c|c|c|}
\hline \multicolumn{5}{|c|}{ Model Summaryb } \\
\hline Model & $\mathrm{R}$ & R Square & $\begin{array}{l}\text { Adjusted R } \\
\text { Square }\end{array}$ & $\begin{array}{l}\text { Std. Error of the } \\
\text { Estimate }\end{array}$ \\
\hline 1 & $.631^{\mathrm{a}}$ & .398 & .382 & 3.362 \\
\hline $\begin{array}{l}\text { a. Pred } \\
\text { Belajar } \\
\text { b. Depe } \\
\text { Sumbe }\end{array}$ & $\begin{array}{l}\text { tors: ( } \\
\text { dent V } \\
\text { : Peng }\end{array}$ & $\begin{array}{l}\text { ant), Gaya } \\
\text { le: Manaje } \\
\text { n Data SP }\end{array}$ & $\begin{array}{l}\text { dup, Literasi } \\
\text { n Uang Saku } \\
\mathbf{2 2 , 2 0 2 1}\end{array}$ & 1omi, Minat \\
\hline
\end{tabular}

Jika dilihat dari tabel 4 menunjukkan bahwa besar R Square sebesar 0,398. Maka dapat disimpulkan bahwa variabel bebas yaitu X1 (literasi ekonomi), X2 (minat belajar), dan X3 (gaya hidup) mempunyai pengaruh sebesar 39.8\% terhadap variabel terikat yaitu Y (manajemen uang saku). Sedangkan sebesar 60.2\% lainnya dipengaruhi oleh variabel lain di luar penelitian.

Adapun hasil persentase dari sumbangan efektif, yakni sebagai berikut:

Tabel 5. Hasil Persentase Sumbangan Efektif

\begin{tabular}{llll}
\hline Variabel & Beta $\times$ Zero-order & Hasil & Persentase \\
\hline X1 (Literasi & $0.009 \times 0.012$ & 0.000108 & $0.01 \%$ \\
Ekonomi) & & & \\
X2 (Minat Belajar) & $0.549 \times 0.600$ & 0.3294 & $32.94 \%$ \\
X3 (Gaya Hidup) & $-0.201 \times-0.340$ & 0.06834 & $6.83 \%$ \\
& Jumlah & & $39.77 \%$ \\
\hline
\end{tabular}

Sumber: Data Olahan Penulis

\subsection{Pengaruh Literasi Ekonomi Terhadap Manajemen Uang Saku}

Berdasarkan hasil penelitian yang dilakukan terhadap siswa kelas XI IPS di SMAN 1 Karangrejo menunjukkan bahwa siswa mendapatkan pengetahuan literasi ekonomi dalam kategori cukup. Ini mengindikasikan siswa cukup memiliki pengetahuan mengenai apa itu ekonomi. Namun hasil penelitian menunjukkan bahwa literasi ekonomi tidak berpengaruh terhadap manajemen uang saku siswa.

Hasil ini menjelaskan bahwa siswa dengan literasi ekonomi baik tidak menjamin memiliki manajemen uang saku yang baik pula. Ini dapat dilihat dari manajemen uang saku siswa yang masuk dalam kategori baik, namun memiliki literasi ekonomi yang cukup. Literasi ekonomi yang dimiliki oleh siswa ini dipengaruhi oleh faktor kurang optimalnya pembelajaran ekonomi yang mereka terima dikarenakan pandemi Covid-19. Banyak sekolah yang terpaksa melaksanakan pembelajaran daring untuk jangka waktu tertentu, sehingga siswa kurang mendapat pantauan dan pengawasan dari guru. Konsekuensi dari kebijakan yang pemerintah lakukan adalah siswa mengalami banyak kendala dalam penyerapan informasi mengenai materi ekonomi.

Selain faktor kurang optimalnya pembelajaran ekonomi, terdapat keterbatasan dalam penelitian ini yaitu rendahnya pengawasan terhadap instrumen penelitian berupa tes kepada siswa kelas XI IPS di SMAN 1 Karangrejo. Ini disebabkan tes literasi ekonomi disebar secara online berupa google form didasarkan atas kondisi pembelajaran di sekolah dilakukan secara daring. Hal ini mengakibatkan siswa kurang maksimal dalam pengerjaan soal literasi ekonomi 
yang bersifat teoritis. Terdapat peluang akan rendahnya kesadaran siswa untuk mengerjakan tes dengan sungguh-sungguh, dan juga sebaliknya. Terdapat peluang di mana siswa dapat mengerjakan tes dengan dukungan faktor lain, selain pengetahuan yang mereka miliki sendiri. Hal ini meliputi kesempatan membuka buku pelajaran, bertanya pada orang lain, dan berselancar di internet.

Menurut Sina (2012:137), makna kemampuan individu yang diungkapkan oleh Matthews mengindikasikan bahwa pemahaman literasi ekonomi mencakup literasi keuangan di dalamnya. Pada penelitian ini didukung oleh Gahagho dkk (2021) bahwa variabel literasi keuangan tidak berpengaruh secara positif terhadap variabel perilaku keuangan. Selain itu, juga pendapat Borden (dalam Laily, 2013) mengenai korelasi antar literasi keuangan dan pengelolaan keuangan masih belum jelas. Namun, hasil ini tidak sejalan dengan penelitian yang dilakukan oleh Leksono (2019) yang menyatakan bahwa literasi keuangan berpengaruh positif terhadap pengelolaan uang saku dan Herawati (2015) yang mengungkapkan bahwa literasi keuangan yang memadai menjadi dasar pengambilan keputusan di masa mendatang. Ini memungkinkan adanya variabel lain yang mempengaruhi cara siswa kelas XI IPS SMAN 1 Karangrejo dalam manajemen uang saku.

\subsection{Pengaruh Minat Belajar Terhadap Manajemen Uang Saku}

Berdasarkan hasil penelitian yang dilakukan terhadap siswa kelas XI IPS di SMAN 1 Karangrejo menunjukkan bahwa siswa memiliki minat belajar di bidang ekonomi dalam kategori tinggi. Hasil penelitian juga menunjukkan bahwa minat belajar berpengaruh positif dan signifikan terhadap manajemen uang saku siswa. Ini mengindikasikan semakin tinggi minat belajar ekonomi, maka akan meningkatkan manajemen uang saku siswa.

Minat belajar ekonomi yang dimiliki siswa kelas XI IPS di SMAN 1 Karangrejo termasuk kategori tinggi, begitupun manajemen uang saku yang mereka terapkan. Namun, hal ini tidak berbanding lurus dengan literasi ekonomi yang masuk dalam kategori cukup. Ini dapat disebabkan oleh siswa lebih cerdas dalam praktek daripada teori yang mereka peroleh. Pada praktiknya, sikap senang dan antusias akan mata pelajaran ekonomi menyebabkan mereka mampu melakukan manajemen uang saku dengan baik.

Hasil penelitian ini sejalan dengan pendapat Nasution (dalam Pratiwi, 2015) bahwa minat merupakan awal penggerak untuk siswa dalam belajar yang digunakan untuk mencapai tujuan yang diinginkan. Tanpa minat untuk belajar ekonomi, siswa akan kesulitan memotivasi diri dalam mempraktekan apa yang mereka ketahui dalam permasalahan ekonomi di kehidupan sehari-hari. Jalal (dalam Kohar, 2011) menyatakan bahwa minat adalah suatu ketertarikan seseorang terhadap suatu objek, sehingga ia mau berkorban untuk menjalani dan melakukannya. Dengan pengorbanan, maka siswa dapat mengendalikan diri dalam manajemen uang saku. Mereka tidak akan mudah tergiur oleh era modern yang mengakibatkan mereka melakukan tindakan pengelolaan uang saku yang tidak bijak.

Hamalik (dalam Rusmiati, 2017) menyatakan bahwa belajar adalah modifikasi atau memperteguh kelakuan melalui pengalaman. Siswa dengan minat belajar yang tinggi tentu memiliki keinginan untuk memperluas pengalaman mengenai apa yang menjadi minatnya. Mereka akan terdorong untuk aktif menerapkan yang mereka ketahui pada kegiatan tertentu, seperti menabung dan melakukan pengelolaan uang saku yang bijak. Ini sejalan dengan pendapat Kusniawati (2014:2) bahwa minat belajar merupakan keinginan kuat untuk belajar 
suatu pekerjaan mereka anggap penting dan minat ini akan tumbuh dan berkembang sesuai kondisi yang ada. Dalam hal ini, siswa telah merefleksikan minat belajar mereka terhadap ekonomi dengan menerapkannya pada manajemen uang saku yang diberikan oleh orang tuanya.

Hal ini sejalan dengan teori Hidayat (dalam Pratiwi, 2015) yang menyatakan indikator digunakan untuk mengetahui minat belajar siswa terhadap sesuatu yang meliputi keinginan kuat dan perasaan senang pada pelajaran ekonomi, perhatian akan materi ekonomi yang mereka terima, perasaan tertarik akan pengetahuan yang mereka peroleh, giat belajar dan mencari pengetahuan berkaitan dengan ekonomi, mengerjakan tugas ekonomi, dan menaati peraturan yang berlaku. Hasil ini didukung oleh penelitian yang dilakukan oleh Chasanah (2018) bahwa minat belajar berpengaruh positif dan signifikan terhadap kemampuan manajemen uang saku siswa.

\subsection{Pengaruh Gaya Hidup Terhadap Manajemen Uang Saku}

Berdasarkan hasil penelitian yang dilakukan terhadap siswa kelas XI IPS di SMAN 1 Karangrejo menunjukkan bahwa gaya hidup yang mereka terapkan termasuk dalam kategori rendah, artinya siswa mengetahui dan memaknai gaya hidup rasional merupakan hal yang penting. Hasil penelitian menunjukkan bahwa gaya hidup berpengaruh negatif dan signifikan terhadap manajemen uang saku siswa. Ini mengindikasikan semakin rendah gaya hidup yang dijalani siswa, maka akan diiringi dengan meningkatnya manajemen uang saku.

Berdasarkan pendapat Azizah (2020:94), gaya hidup menggambarkan keseluruhan diri seseorang dalam berinteraksi dengan lingkungannya. Pada sisi ekonomi, siswa dapat merefleksikan dirinya dengan perilaku yang mampu menerapkan manajemen uang saku yang baik. Ini sesuai dengan pendapat Hawkins (dalam Hariyono, 2015) yang menyatakan bahwa gaya hidup seseorang mempengaruhi kebutuhan, keinginan, dan perilakunya. Hal ini dapat dilihat dari bagaimana siswa menjalani gaya hidup yang rasional sesuai kebutuhan dan keinginan berdasarkan prinsip-prinsip ekonomi, serta berpengaruh terhadap perilaku mereka dalam manajemen uang saku yang bijak.

Sedangkan Sunarto (dalam Mandey, 2009), indikator gaya hidup mencakup aktivitas atau kegiatan apa yang dilakukan siswa di waktu luang, apa yang mereka beli sebagai kebutuhan, minat dalam menentukan prioritas uang dan waktu yang dimiliki, serta pandangan siswa dalam menanggapi sesuatu berkaitan dengan aktivitas ekonomi. Indikator tersebut menjadi dasar bagaimana siswa melakukan keputusan pembelian. Selain itu, indikator tersebut menjelaskan bagaimana mereka mengatur dan mengelola uang sakunya.

Siswa kelas XI IPS di SMAN 1 Karangrejo memiliki bentuk gaya hidup yang modern dan rasional. Ini terlihat perilaku mereka yang tidak terpenjara oleh konsumerisme di era digital. Mereka dapat mengendalikan diri dengan baik dan melakukan manajemen uang saku dengan bijak. Siswa tidak berlaku boros dan memilih meluangkan waktunya untuk kegiatan yang lebih bermanfaat dibandingkan membelanjakan uang. Dalam hal ini adalah uang saku yang diberikan oleh orang tua mereka. Mereka telah memahami untuk mengalokasikan uang saku untuk membeli barang berdasarkan manfaatnya, baik dalam jangka pendek maupun jangka panjang. Mereka juga melakukan banyak pertimbangan sebelum melakukan keputusan ekonomi. Siswa mengetahui bahwa kebutuhan primer yang bersifat mendesak harus 
didahulukan di atas kebutuhan yang lain dan bertanggung jawab atas pengelolaan keuangan mereka sendiri.

Hasil ini sejalan dengan penelitian yang dilakukan oleh Tambunan (2017) bahwa gaya hidup berpengaruh terhadap pengelolaan keuangan. Penelitian ini juga diperkuat dengan Lestari \& Putri (2019) yang menunjukkan bahwa gaya hidup berpengaruh terhadap manajemen keuangan. Azizah (2020) mendukung dengan pendapat bahwa semakin baik seorang milenial mengatur gaya hidup yang benar, maka semakin baik pula perilaku keuangannya. Namun hal ini bertentangan dengan penelitian yang dilakukan oleh Putri (2021) bahwa gaya hidup tidak berpengaruh secara signifikan terhadap pengelolaan keuangan.

\section{Simpulan}

Berdasarkan hasil penelitian yang telah dilakukan, maka dapat disimpulkan bahwa: (1) Literasi ekonomi tidak berpengaruh secara signifikan terhadap manajemen uang saku kelas XI IPS SMA Negeri 1 Karangrejo. Hal ini berarti cara siswa melakukan manajemen uang saku tidak dipengaruhi oleh literasi ekonomi yang mereka miliki; (2) Minat belajar berpengaruh positif dan signifikan terhadap manajemen uang saku kelas XI IPS SMA Negeri 1 Karangrejo. Hal ini berarti semakin tinggi minat belajar siswa di bidang ekonomi, maka semakin baik pula manajemen uang saku; (3) Gaya hidup berpengaruh negatif dan signifikan terhadap manajemen uang saku kelas XI IPS SMA Negeri 1 Karangrejo. Hal ini berarti semakin rendah gaya hidup yang mereka terapkan, maka semakin baik manajemen uang saku.

\section{Daftar Rujukan}

Azizah, N. S. (2020). Pengaruh literasi keuangan, gaya hidup pada perilaku keuangan pada generasi milenial. Prisma (Platform Riset Mahasiswa Akuntansi), 1(2), 92-101.

Chasanah, N. (2018). Pengaruh IQ, minat belajar, dan literasi ekonomi terhadap kemampuan manajemen uang saku siswa di kelas XI IPS SMA Negeri 2 Malang tahun ajaran 2017/2018 (Doctoral dissertation, Universitas Negeri Malang).

Fitriani, I. (2018). Pengaruh uang saku, gaya hidup, dan modernitas terhadap perilaku konsumsi produk fashion siswa kelas XI IPS SMA An-Nur Bululawang (Doctoral dissertation, Universitas Negeri Malang).

Fitriastuti, F. (2013). Pengaruh Interaksi Sosial dalam Keluarga dan Minat Belajar Siswa terhadap Prestasi Belajar Siswa. OIKONOMIA-Jurnal Pendidikan Ekonomi, 2(3).

Fiqriyah, R., \& Wahyono, H. (2016). Pengaruh pengelolaan uang saku, modernitas, kecerdasan emosional, dan pemahaman dasar ekonomi terhadap rasionalitas perilaku konsumsi siswa kelas X IIS MAN 1 Malang. Jurnal Pendidikan Ekonomi (Economic Education Journal), 9(1).

Gahagho, Y. D., Rotinsulu, T. O., \& Mandei, D. (2021). Pengaruh literasi keuangan sikap keuangan dan sumber pendapatan terhadap perilaku pengelolaan keuangan mahasiswa fakultas ekonomi dan bisnis unsrat dengan niat sebagai variabel intervening. Jurnal EMBA: Jurnal Riset Ekonomi, Manajemen, Bisnis dan Akuntansi, 9(1).

Hariyono, P. (2015). Hubungan Gaya Hidup dan Konformitas dengan Perilaku Konsumtif pada Remaja. eJournal Psikologi.

Herawati, N. T. (2015). Kontribusi pembelajaran di perguruan tinggi dan literasi keuangan terhadap perilaku keuangan mahasiswa. Jurnal pendidikan dan Pengajaran, 48(1-3).

Kohar, Abdul. (2011). Minat Siswa Terhadap Kegiatan Ekstrakurikuler Seni Baca Al-Qur'an di MTs Islamiyah Sawangan Depok.

Kusniawati, dkk. (2014). Pengaruh Minat Belajar Terhadap Hasil Belajar Siswa Mata Pelajaran IPS Terpadu di SMPN 2. Jurnal Pendidikan Ekonomi, 4 (3), 1-9.

Laily, N. (2013). Pengaruh Literasi Keuangan Terhadap Perilaku Mahasiswa dalam Pengelolaan Keuangan. Journal of Accounting and Business Education, 1 (4). 
Jurnal Ekonomi, Bisnis dan Pendidikan, 1(8), 2021, 753-762

Leksono, A. W., \& Vhalery, R. (2019). Pengaruh Self-Knowledge Dan Self-Deception Terhadap Pengelolaan Uang Saku. Research and Development Journal of Education, 6(1), 28-40.

Mandey, Silvya L. (2009). Pengaruh Faktor Gaya Hidup terhadap Keputusan Pembelian Konsumen. Jurnal Vol 6 No. 1

PUTRI, D. A. R. (2021). Analisis Pengaruh Literasi Keuangan, Sikap Keuangan, dan Gaya Hidup Terhadap Perilaku Pengelolaan Keuangan Mahasiswa Akuntansi (Doctoral dissertation, Universitas Jenderal Soedirman).

Pratiwi, N. K. (2017). Pengaruh tingkat pendidikan, perhatian orang tua, dan minat belajar siswa terhadap prestasi belajar bahasa indonesia siswa smk kesehatan di kota tangerang. Pujangga, 1(2), 31.

Rosidah, E. (2019). Pengaruh literasi ekonomi, pengelolaan uang saku, kontrol diri, dan intensitas penggunaan media sosial terhadap rasionalitas konsumsi mahasiswa Prodi S1 Pendidikan Ekonomi angkatan 2016 FE UM (Doctoral dissertation, Universitas Negeri Malang).

Rusmiati, R. (2017). Pengaruh Minat Belajar Terhadap Prestasi Belajar Bidang Studi Ekonomi Siswa MA AL FATTAH Sumbermulyo. Utility: Jurnal Ilmiah Pendidikan dan Ekonomi, 1(1), 21-36..

Sina, Peter G. (2012). Analisis Literasi Ekonomi. Jurnal Economia, 8 (2), 135-143

Ulfah, M., \& Syahrudin, H. (2013). Pengaruh Literasi Ekonomi terhadap Perilaku Konsumsi Mahasiswa Pendidikan Ekonomi Fkip Untan. Jurnal Pendidikan dan Pembelajaran Khatulistiwa, 3(3). 